\title{
Science, Technology, and Society (STS) Learning in Senior High School Chemistry Class
}

\author{
Rahmi Fartiwi ${ }^{1}$, M. Adlim ${ }^{2}$,and Cut Nurmaliah ${ }^{3}$ \\ Science Education Master's Program, Universitas Syiah Kuala, Banda Aceh, Indonesia ${ }^{1}$ \\ Department of Chemistry Education, Universitas Syiah Kuala, Banda Aceh, Indonesia ${ }^{2}$ \\ Department of Biology Education, Universitas Syiah Kuala, Banda Aceh, Indonesia ${ }^{3}$
}

\begin{abstract}
\{fartiwirahmi@gmail.com¹,adlim@unsyiah.ac.id²,cutnurmaliah@fkip.unsyiah.ac.id³
\end{abstract}
\begin{abstract}
This research is started by developed STS student-worksheet, validated and applied in senior high school chemistry class. The student worksheet was developed by using R \& D with the ADDIE model following the STS syntaxes. The worksheet was designed based on popular issue in everyday life and provide solutions according to science and technology. The students were given a problem statement and asked to plan and to run experiments to solve the problem. They have to videotape their work and reported their finding to the teachers. The student worksheet was considered valid by the experts before being applied. The validation score was $93.90 \%$ with a very feasible and valid category. The score of student worksheet was $86.25 \%$ of expectation. The main students' score on students' activities in class 95.31. Teacher and students gave positive responses to STS learning as shown score of positive respond reaching nearly maximum $(94.50 \%)$. Nearly all agree that the student worksheet can be used as teaching material in chemistry learning.
\end{abstract}

Keywords. Worksheet, STS, learning.

\section{Introduction}

The knowledge development in the modern world goes very fast and has an impact on social change [1], [2]. Since information on science and technology can be accessed easily, then often students prefer to memorize data instead of to learn to think and to solve the problem. Ideally, the role of the teacher is to guide student to choose an essential concept and to train students to think, to analyze and to solve the problems in their daily life [3]. Teachers need to look for technology-related issues or relevant problems in everyday life, and then ask the student to creatively solve the problems using relevant concepts either independently or with teacher guidance [4]. STS learning is contextual learning and the application of science and technology in the context of human life. STS learning means integrating understanding and utilization of science, technology, and society. The application of science and technology is implemented as human skills that are beneficial for the students and society [5].

Some previous studies reported that STS learning significantly improved students' understanding of science concepts [6], [7] Students also mastered better the concept of chemical equilibrium [8]. After STS learning, student has more motivation to learn chemistry. They learn it in the context of real life by exploring how science and technology can contribute to society and led them to develop their skills [9], [10]. In this learning model, students expressed their 
ideas by identifying, analyzing and finding solutions to issues or problems faced in daily life [11], [12].

Following the STS model, the student worksheet is deal to the issues or problems that are often found in the community. The problem statement in this worksheet are concerning issue in the Indonesian community, which are how to differentiate pure honey from manipulated ones. How to determine the contamination of poly-acetylene resin (plastic) in fried food and how to identified borax contaminating food. The students are expected to solve this problem by using chemistry concept which is not common in regular high school regular chemistry curriculum. Asking the student to videotape of their report is part of the agenda to motivate them to run the project [13].

\section{Methods}

This study uses Research and Development (R \& D) methods with model Analysis, Design, Development, Implementation, and Evaluation (ADDIE). This research model verified the previous reports [14], [15]. The procedure was started by need assessment for STS worksheet, analysis of curriculum and school supporting facilities, design the STS worksheet based on the syntax, composing the worksheet and related teaching material, implementation in small group and finally evaluation. The STS worksheet quality is validated by experts based on the format, the STS syntax and the content, language, and layout, illustration and completeness of components. All of the aspects have a score of $93.90 \%$ and is feasible to apply in chemistry class. Two high schools that are SMAN 3 Banda Aceh (31 students) representing an accredited high school and SMAN 14 Iskandar Muda (21 students) as a moderate accredited school. The school was chosen by using a disproportionate stratified random sampling technique. Data were collected by using student assessment worksheets, observation worksheets of student activities and questionnaire for teacher and student responses on STS worksheet implementation.

\section{Result and Discussion}

Four groups of student were conducted each project that was developing scientific methods on (1) analysis the purity sold honey, (2) analysis of fried foods that containing plastic, (3) analysis of foods that containing borax, and (4) purification of used cooking oil by using charcoal. Each of these projects was narrated as a problem statement in the student worksheet.

Represent STS student worksheet format as follow :

\section{Name : \\ Project title : \\ Group : \\ 1. Initial stage}

....theoretical background to introduce the problem to be solve .... (provided by teacher in order to write problem statement)

(a) Problem statement :

(b) Hypothesis

\section{Concept Formulation stage}

(a) material and equipment needed to run Experiment

(b) experimental procedure

(c) observation sheet/table :

\section{Concept Application stage} write 3 examples the application of science you just learnt in community!

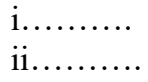

4. Consolidation of Concept Stage

Did your experiment data answer your hypothesis?

compare your hypothesis with you experimental finding

Conclusion : 
The students carried out their project by following several steps according to STS syntax Primastuti \& Atun (2018) as follows: (1) initiation stage; the students read and comprehend the problems statement in the worksheet, discussed within their peer to formulate hypotheses. (2) The concept formation stage, students, looked for an alternative solution and conducting experiments. Students process all data, recorded in the form of observation tables and analyzed it. Students search and record as much as possible information to obtain new findings. The students documented their work by videotaping. (3) Concept application phase, the students answered how chemistry contributed to manufacturing goof (food) and how chemistry solve the community concern issue (analysis in food contamination). Students are given the opportunity to look for answers from various sources and literature. (4) Concept stabilization phase, students reviewed their hypothesis in accordance experiment finding, before formulated the conclusions. (5) The evaluation phase, the students must present their work including playing the video made. Student activities and representative of their work report are shown in Figures 1.

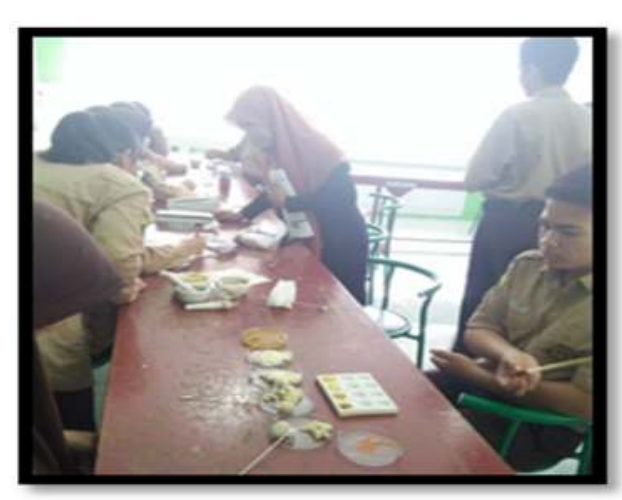

(a)

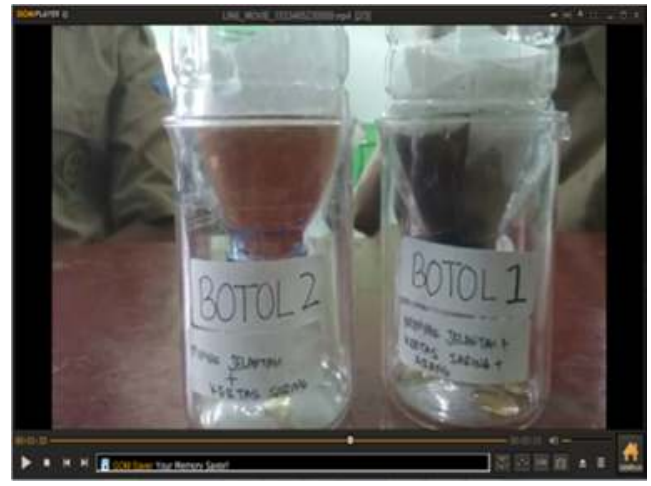

(b)

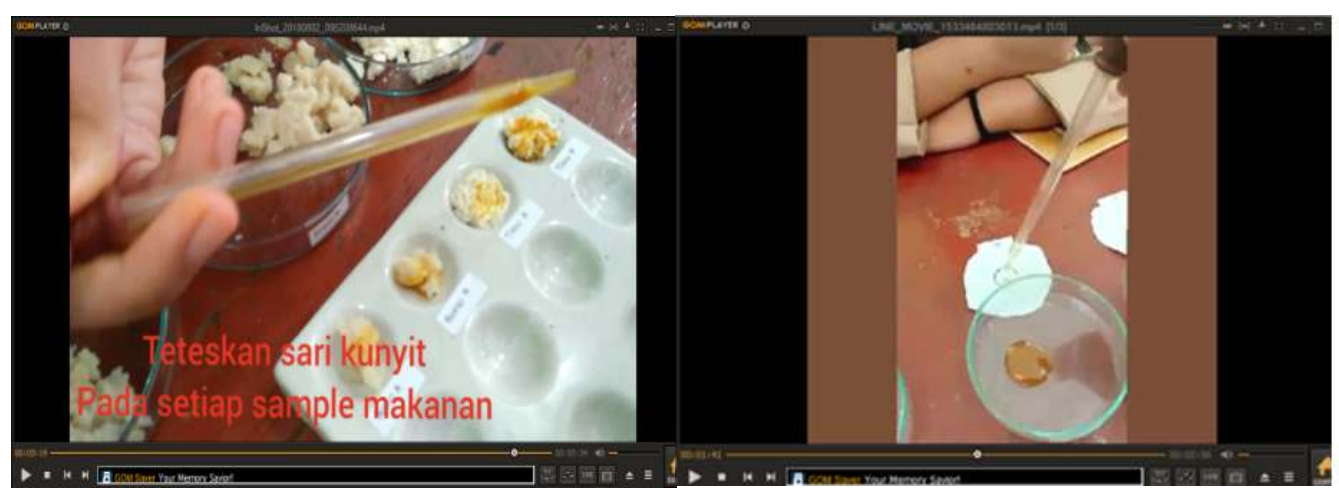

(c)

(d) 


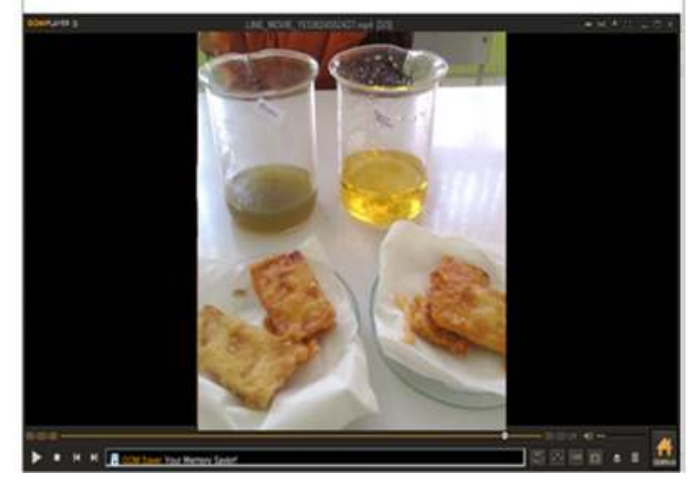

(e)

\section{1 Student Activity Scores}

Observation of student activities is a very important thing to see the success of the learning process. Activities observed from the preliminary stage to the closing of learning. Student activities during the implementation of STS learning are observed based on the observation sheet rubrics. Student activity score is shown in Table 1.

Table 1. Student Activity Scores.

\begin{tabular}{lcc}
\hline \multirow{2}{*}{\multicolumn{1}{c}{ Aspect of assessment }} & \multicolumn{2}{c}{$\begin{array}{c}\text { Assessment of students' activity } \\
(\%)\end{array}$} \\
\cline { 2 - 3 } & $\begin{array}{c}\text { Good high } \\
\text { school }\end{array}$ & $\begin{array}{c}\text { Moderate-high } \\
\text { school }\end{array}$ \\
\hline Listen to the explanation of STS based learning & 93.75 & 87.50 \\
\hline $\begin{array}{l}\text { Understand the worksheet and discuss the formulation of the } \\
\text { problem and hypothesis }\end{array}$ & 87.50 & 87.50 \\
\hline Prepare experimental tools and materials & 93.75 & 93.75 \\
\hline Prepare recording equipment to make video documentation & 100.00 & 81.25 \\
\hline Do experiment & 100.00 & 93.75 \\
\hline Working on the worksheet & 93.75 & 81.25 \\
\hline Presenting the results of the experiment with video documentation & 93.75 & 87.50 \\
\hline Fill the response questionnaire & 100.00 & 100.00 \\
\hline Average & 95.31 & 89.06 \\
\hline
\end{tabular}

During implementation STS in class, the student activities score were very high that was $95.31 \%$ and $89.06 \%$ for high and moderate accredited schools. This suggested that STS worksheet can be implemented even in regular high school. The existence of this approach makes students more active independently or in groups to conduct experiments, make observations, collect data and process data [16], [17]

This finding might correlate with STS worksheet systematically that helps students in the active learning process. Providing problems in life context would have motivated the student to learn science with the scientific method. The STS student worksheet guide students to learn the problems related to science concepts and apply them in their daily life [18]. 


\subsection{Student Capacity Score on Completing STS Worksheet}

The student capacity to complete the STS worksheet was reviewed by the teacher on several aspects by using an assessment rubrics. The student capacity score is shown in Table 2. It shows that all aspect gave high score both in moderate and good high school.

Table 2. Result of worksheet assessment at SMAN 3 Banda Aceh and SMAN 14 Iskandar Muda.

\begin{tabular}{lcc}
\hline \multirow{2}{*}{ Aspect of assessment } & \multicolumn{2}{c}{ Assessment of worksheet content (\%) } \\
\cline { 2 - 3 } & Good high school & Moderate-high school \\
\hline Formulation of the Problem & 93.75 & 87.50 \\
\hline Hypothesis & 87.50 & 87.50 \\
\hline Observation data & 100.00 & 93.75 \\
\hline Task concept application & 81.25 & 81.25 \\
\hline Conclusion & 87.50 & 81.25 \\
\hline Average & 90.00 & 86.25 \\
\hline
\end{tabular}

Table 2 shows that the average student capacity completing a worksheet in good high school is not much different from the moderate one that was 90.00 and $86.25 \%$. This is due to STS learning can foster the interest and motivation of the students in learning chemistry. This finding is in line with the research of Abualrob \& Shah [19] that the use of STS based teaching materials can increase the students' interest in learning science and can help them apply the knowledge to their lives. It also encouraged the student to explain natural phenomena and attempted to use science and technology to solve problems in society [20].

\subsection{Assessment on Students' Video Documentation}

Asking the student to present their experiment by using video is an agenda to encourage students to use such technology in their life. Students learn several skills such as story (manuscript) making, shooting, editing, and reporting. Students' work was assessed by using rubrics on several aspects as shown in Table 3. Video assessment documentation can be seen in Table 3.

Table 3. Video Documentation Assessment.

\begin{tabular}{lcc}
\hline \multirow{2}{*}{ Aspect of assessment } & \multicolumn{2}{c}{ Video assessment (\%) } \\
\cline { 2 - 3 } & Good high school & Moderate high school \\
\hline Video display & 93.75 & 87.50 \\
\hline Video content & 87.50 & 81.25 \\
\hline Creativity & 87.50 & 81.25 \\
\hline Duration time & 87.50 & 75.00 \\
\hline Average & 89.06 & 81.25 \\
\hline
\end{tabular}

Table 3 shows that almost all aspects of the video were well prepared by students and students from the good high school have a higher score. This difference might correlate with student intelligence, their skill in using technology and creativity. Good high school has many 
smart students since it has a higher competitive entrance exam. Video making provides opportunities for students to be able to use their abilities and creativity in creating works [21].

\subsection{Student Responds on STS Worksheet Implementation}

Data on students' and teacher's response to STS worksheet were obtained by giving a questionnaire containing ten questions to teachers from both schools. The questions were on the accomplishment of learning objectives, the understanding of the STS syntax, etc. as shown in Table 3. The results obtained were all teachers giving a response of $100 \%$. This is by the research of Amirshokoohi [22] that the importance of a teacher applying STS learning so that it can increase the knowledge and interests of students in learning. Furthermore, students were also given a questionnaire containing questions to find out their responses to the student worksheet that had been applied. The responses of students to STS learning are presented in Table 4.

Table 4. Students' responses to STS worksheet

\begin{tabular}{lcc}
\hline \multirow{2}{*}{\multicolumn{1}{c}{ Indicator }} & \multicolumn{2}{c}{ Percentage of "agree" responses } \\
\cline { 2 - 3 } & $\begin{array}{c}\text { Good high } \\
\text { school }\end{array}$ & $\begin{array}{c}\text { Moderate-high } \\
\text { school }\end{array}$ \\
\hline The accomplishment of learning objectives & 100.00 & 100.00 \\
\hline Broadening vision in science & 100.00 & 100.00 \\
\hline Providing good reading material & 80.65 & 95.24 \\
\hline Ease in understanding the STS syntax & 100.00 & 95.24 \\
\hline Ease in understanding practicum procedures & 96.77 & 85.71 \\
\hline Ease in understanding question & 100.00 & 100.00 \\
\hline Interesting student worksheet & 100.00 & 95.24 \\
\hline Motivating in learning chemistry & 90.32 & 85.71 \\
\hline Awareness of the use of chemicals & 100.00 & 100.00 \\
\hline Making videos documentation is an interesting task & 93.55 & 71.43 \\
\hline Average & 96.13 & 92.86 \\
\hline
\end{tabular}

Table 4 shows that all indicator in STS worksheet implementation were responding positively by students in both types of high schools. The percentage of positive respond is only much different in making a video where the moderate high school show less antistatic as shown by a score of $71.43 \%$. This consistent with their capacity in video documentation preparation. The students from this school acquired a lower score in making a video. This finding is consistent with the previous research conducted by Rachmawati \& Admoko [23] which shows that students gave a positive response to STS based learning because it stimulated motivation in science learning.

\section{Conclusion}

Based on need assessment, STS worksheet has not been familiar among the teacher in the city of Banda Aceh. Respondent suggested to develop it and implemented in a high school class. STS worksheet has been developed, and it has been validated by experts with a high score before implemented in the classroom. Four themes of STS worksheet has been applied in good (high accredited) and moderate high school). Student activity during implementation was high. Student completed the worksheet by following the STS syntax. Students' capacity in completing the worksheet was very high in both types of schools. Student score in reporting their work by 
videotaping was higher in good higher school than in the moderate one. Students gave positive respond on the implementation of STS worksheet. Their enthusiastic on this model was more in good high school. The teacher recommended this worksheet to be a part of the active learning material.

\section{ACKNOWLEDGEMENT}

I would like to thank all the teachers and student of SMAN 3 Banda Aceh and SMAN 14 Iskandar Muda for assistance and participation during the study.

\section{REFERENCES}

[1] C. Huaxiong and W. Jian, "Evaluation of academic competitiveness based on scientific research papers," Int. J. Sci. Technol. Soc., vol. 6, no. 5, pp. 78-87, 2018.

[2] E. T. Smitha and P. K. Aruna, "Effect of science technology society approach on achievement motivation in biology of secondary school students of kasaragod district," IOSR J. Humanit. Soc. Sci., vol. 19, no. 4, pp. 54-58, 2014.

[3] L. Kok and R. van Schoor, "A science-technology-society approach to teacher education for the foundation phase: Students' empiricist views," South African J. Child. Educ., vol. 4, no. 1, p. 16, 2014.

[4] N. Afni, Khairil, and Abdullah, "Penerapan pendekatan STM (sains teknologi masyarakat) pada konsep pencemaran lingkungan untuk meningkatkan hasil belajar dan kemampuan berpikir kritis di SMA NEGERI 4 wira bangsa meulaboh,” J. Biot., vol. 2, no. 2, pp. 77-137, 2014.

[5] A. Poedjiadi, Sains, teknologi masyarakat. Bandung: Remaja Rosdakarya, 2005.

[6] B. Akcay and A. Hakan, "Effectiveness of science-technology-society (STS) instruction on student understanding of the nature of science and attitudes toward science," Int. J. Educ. Math. Sci. Technol., vol. 3, no. 1, pp. 37-45, 2015.

[7] S. Havu-Nuutinen, S. Kärkkäinen, and T. Keinonen, "Changes in primary school pupils' conceptions of water in the context of science, technology, and society (STS) instruction," Int. Res. Geogr. Environ. Educ., 2017.

[8] M. Primastuti and S. Atun, "Science Technology Society (STS) learning approach: an effort to improve students' learning outcomes," J. Phys. Conf. Ser., vol. 1097, p. 12062, Sep. 2018.

[9] M. A. Chowdhury, "The integration of science-technology-soecity/science-technologysociety-environment and socio-scientific-issue for effective science education and science teaching," Electron. J. Sci. Educ., vol. 20, no. 5, pp. 19-38, 2016.

[10] C. Bettencourt, J. L. Velho, and P. A. Almeida, "Biology teachers' perceptions about science-technology-society (STS) education," Procedia - Soc. Behav. Sci., vol. 15, pp. 3148-3152, 2011.

[11] P. Sengdala and C. Yuenyong, "Enhancing laos students' understanding of nature of science in physics learning about atom for peace," Eur. J. Sci. Math. Educ., vol. 2, no. 2, pp. 119-126, 2014.

[12] T. Chantaranima and C. Yuenyong, "The outcomes of teaching and learning about sound based on science technology and society (STS) approach," Procedia-Soc. Behav. Sci., vol. 116, pp. 2286-2292, 2014.

[13] Turyati, M. Muchtarom, and Winarno, "Pengaruh penggunaan media video edukasi 
terhadap hasil belajar pkn siswa kelas Vii smp negeri 2 gondangrejo," PKn progresif, vol. 11 , no. 5, pp. 256-267, 2016.

[14] R. P. Sari, M. Adlim, and A. Gani, "STEM learning in regular and vocational high schools on the topic of scientific menu card fabrication," in Journal of Physics: Conference Series, 2018, vol. 1008.

[15] M. Mahyuna, M. Adlim, and I. Saminan, "Developing guided-inquiry-student worksheets to improve the science process skills of high school students on the heat concept," in Journal of Physics: Conference Series, 2018, vol. 1088.

[16] C. P. Utami and I. Wilujeng, "Development of web student worksheet based on science, technology and society (STS) on optic material in senior high school," in Journal of Physics: Conference Series, 2018, vol. 1097, no. 1.

[17] H. S. Zahara and S. Atun, "Effect of science-technology-society approach on senior high school students' scientific literacy and social skills," J. Turkish Sci. Educ., vol. 15, no. 2, pp. 30-38, 2018.

[18] H. Lestari, S. Ayub, and H. Hikmawati, "Penerapan model pembelajaran sains teknologi masyarakat (STM) untuk meningkatkan hasil belajar fisika siswa kelas VIII SMPN 3 mataram," J. Pendidik. Fis. dan Teknol., vol. 2, no. 3, pp. 111-115, 2018.

[19] M. M. A. Abualrob and M. Shah, "Science Technology and Society Modules Development Process and Testing on its Effectiveness," Procedia - Soc. Behav. Sci., vol. 46, pp. 811-816, 2012.

[20] W. S. Dini, Asrul, and L. Dwiridal, "Pengembangan LKS berbasis sains teknologi masyarakat pada konsep kalor dan prinsip konservasi energi untuk pembelajaran siswa kelas X semester 2 sman 4 pariaman," Pilla, vol. 2, pp. 97-104, 2013.

[21] H. Greene and C. Crespi, "The value of student created videos in the college classrooman exploratory study in marketing and accounting," Int. J. Arts Sci., vol. 5, no. 1, pp. 273-283, 2012.

[22] A. Amirshokoohi, "Impact of STS issue oriented instruction on pre-service elementary teacher view and perceptions of science, technology and society," Int. J. Environ. Sci. Educ., vol. 1, no. 4, pp. 359-38, Dec. 2016.

[23] M. Rachmawati and S. Admoko, "Penerapan model pembelajaran sains teknologi masyarakat untuk meningkatkan literasi sains siswa Smkn 3 Bojonegoro kelas X teknik pemesinan pada materi fluida statis," J. Inov. Pendidik. Fis., vol. 6, no. 3, pp. 91-99, 2017. 